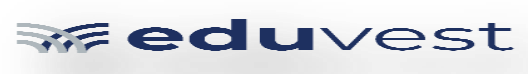

Eduvest - Journal of Universal Studies

Volume 1 Number 8, August 2021

p- ISSN 2775-3735 e-ISSN 2775-3727

\title{
THE EFFECT OF ADDITIONAL MANALAGI (MALUS SYLVESTRIS) APPLE CIDER JUICE ON CHEWY CANDY'S SENSORIC QUALITY
}

\author{
Farihah Bilqis Safira, Mariani, Mutiara Dahlia \\ State University of Jakarta \\ E-mail: bilqisfarihah1@gmail.com, mariani.ikk09@gmail.com, \\ mutiaradahlia63@gmail.com
}

\begin{tabular}{|c|c|}
\hline ARTICLE INFO & ABSTRACT \\
\hline $\begin{array}{l}\text { Received: } \\
\text { July, 24 }{ }^{\text {th }} 2021 \\
\text { Revised: } \\
\text { August, } 16^{\text {th }} 2021 \\
\text { Approved: } \\
\text { August, } 18^{\text {th }} 2021\end{array}$ & $\begin{array}{l}\text { This study aims to study the effect of adding manalagi apple } \\
\text { juice to the sensory quality of chewy candy on the aspect of } \\
\text { color, taste, aroma, and texture. This research was conducted } \\
\text { in the Pastry \& Bakery Laboratory of the Culinary Education } \\
\text { Study Program Faculty of Engineering State University of } \\
\text { Jakarta and was carried out in April } 2021 \text {. This study uses an } \\
\text { experimental method with different percentages namely } 20 \% \text {, } \\
40 \% \text {, and } 60 \% \text { then a hedonic test is carried out on } 15 \\
\text { moderately trained panelists. The results of the descriptive } \\
\text { analysis show the average value in the color aspect } 3.1 \text { has a } \\
\text { lightgreen categories with a percentage of } 20 \% \text { in the sweet } \\
\text { taste aspect } 4.0 \text { categories of sweetness with a percentage of } \\
20 \% \text {, in the manalagi apple flavor aspect } 4.0 \text { feels manalagi } \\
\text { apple with a percentage of } 20 \% \text {, in the aspect of manalagi } \\
\text { apple aroma } 3.6 \text { in the manalagi apple-scented category with } \\
\text { a percentage of } 60 \% \text { and on the texture aspect } 4.0 \text { has a } \\
\text { chewy category with a percentage of } 40 \% \text { Based on the } \\
\text { hypothesis test using the Friedman test, it is stated that all } \\
\text { aspects need to be continued with the Tuckey's test and the } \\
\text { best result obtained are: color aspect = } 2 \text { was significantly } \\
\text { different and } 1 \text { not significantly different with a value of } 3.1 \\
\text { at } 20 \% \text {; sweetness aspect = } 3 \text { not significantly different from } \\
4.0 \text { at } 20 \% \text {; the apple taste aspect of manalagi = } 3 \text { was not } \\
\text { significantly different from the value } 4.0 \text { at } 20 \% \text {; the apple }\end{array}$ \\
\hline
\end{tabular}

\begin{tabular}{ll}
\hline & Farihah Bilqis Safira, Mariani, Mutiara Dahlia. (2021) The Effect of Additional \\
& Manalagi (Malus Sylvestris) Apple Cider Juice on Chewy Candy's Sensoric \\
& Quality. Journal Eduvest. 1(8): 757-764 \\
How to cite: & $2775-3727$ \\
E-ISSN: & https://greenpublisher.co.id/
\end{tabular}




\begin{tabular}{ll}
\hline & $\begin{array}{l}\text { aroma aspect of manalagi }=3 \text { was not significantly different } \\
\text { with a value of } 3.6 \text { at } 60 \% \text {; and texture aspect }=3 \text { was not } \\
\text { significantly different from the value } 4.0 \text { at } 40 \% .\end{array}$ \\
\hline KEYWORDS & Manalagi Apple Juice, Sensory Quality, and Chewy Candy \\
\hline CC) (7) (O) & This work is licensed under a Creative Commons \\
\hline
\end{tabular}

\section{INTRODUCTION}

Sensory quality is a collection of words to describe the characteristics of a food product, including color, appearance, shape, taste, and texture (Nisrina, 2018). The characteristics of the general appearance of the product include color, size, shape, surface texture, level of purity and product carbonation (Sipahelut, Rejeki, \& Patty, n.d.). In food product commodities, color has an important role as attractiveness, identification, and quality attributes (Kurniati, Silvia, \& Efendi, 2016).

Sensory testing (panel testing) plays an important role in product development by minimizing risk in decision making. Panelists can identify sensory properties that will help to describe the product. Sensory evaluation can be used to assess any desired or unwanted changes in the product or formulation ingredients, identify areas for development, determine whether optimizations have been achieved, evaluate competing products, observe changes that occur during processing or storage, and provide the necessary data for product promotion. Consumer acceptance and liking or preference, as well as correlations between sensory and chemical or physical measurements can also be obtained by sensory evaluation.

According to (Widiati, 2019) the hardness level of candy is grouped into 2, namely, hard candy and soft candy. Hard candy will not deform when pressed and will even break if forced. Meanwhile, soft candy is a candy that is easy to change with just a little pressure, for example chewy candy and bubble gum (Mustollah, 2016). Based on SNI 3547-2-2008, soft candy has a soft texture or becomes soft when chewed. One type of candy that is classified as soft candy is chewy candy. Chewy candy is made by cooking sugar until it reaches the desired solid, then adding gelling ingredients (gelatin, agar, pectin, and carrageenan) and adding flavor, color, and finally printing.

The texture that arises is largely determined by the crystal structure formed, which can be directed according to the industry by adjusting the composition of the material and the type of application of the manufacturing technology used. In hard candy, the crystallization process is prevented in such a way by adjusting the composition of sucrose and glucose syrup, so that after the cooking and cooling process is limited, it is immediately continued to the printing process. While the process of making chewy candy is different, where after the cooking process, a cooling process is carried out, using a cooling drum or a cooling table. Which is then followed by the pulling/beating process which aims to recrystallize.

Manalagi apple is a horticultural commodity that is widely developed in Indonesia (Sutanto \& Ambarsari, 2016), one of which is Batu City and Pujon District, Malang Regency, East Java (Muhlisin, Karindah, \& Rahardjo, 2015). The total production of apples in Batu City reached 708,438 quintals/year, while the number of apples rejected (subgrade) was $10 \%$ of the apple production. Apples have a fairly high nutritional content, especially vitamins (Hamidah, 2015) and minerals such as calcium, phosphorus, iron, potassium, carbohydrates, fats, protein, niacin, riboflavin, vitamins A, B1, B2, and vitamin C. 
According to Soelarso, the quality standards that apply to apples are based on weight, size, and quantity per kilogram. Consists of 4 grades, namely: Grade $\mathrm{A}=15.90 \%$ $(3-4$ pieces $/ \mathrm{kg}$ ), Grade $\mathrm{B}=45.20 \%$ (5 - 7 pieces $/ \mathrm{kg})$, Grade $\mathrm{C}=29.60 \%(8-10$ pieces $/ \mathrm{kg}$ ), and Grade $\mathrm{C}=29.60 \%$ ( $8-10$ pieces $/ \mathrm{kg}$ ), and Grade $\mathrm{D}=7.00 \%(11-15$ pieces $/ \mathrm{kg}$ ). Apples that are very small (krill) and broken / defective / damaged are not included in classes A to D as much as $2.30 \%$. Each grade of apple has a different size. Grade A has the largest size and grade D has the smallest size. While the damaged or defective are included in grade E. In general, grade E does not have a specific size because if grades $A$ to $\mathrm{D}$ are damaged or defective, they will be included in grade $\mathrm{E}$. The diameter sizes of each grade are: grade A $7-8 \mathrm{~cm}$, grade B $6-7 \mathrm{~cm}$, grade C $5-6 \mathrm{~cm}$, and grade $\mathrm{D}<5 \mathrm{~cm}$.

According to (Nurdjannah, 2007) fruit juice is one of the processed fruit products that has long been known. The high nutritional content, refreshing taste (Sihombing, 2013) and the emergence of public awareness of the importance of health encourage the development of the fruit juice industry as a substitute for soft drinks (Azizah, 2019), coffee or tea. Making fruit juice is intended to increase the shelf life of fruits (Sari, 2016). Each type of fruit has a slightly different juice making, but the principle is the same (Adnandiyanta \& Hermawan, 2016). Fruit juice is made by crushing the flesh of the fruit and then pressing it to get the juice (Sa'adah \& Estiasih, 2014), then the liquid is filtered, bottled, and pasteurized to make it last longer (Sutanto \& Ambarsari, 2016).

Fruit juice is a soft drink made from fruit juice and mineral water with or without the addition of sugar and permitted food additives. The advantage that can be obtained from the consumption of fruit juice or juice is the ease of drinking it. In addition, the liquid consistency of the juice allows the dissolved substances to be easily absorbed by the body. By making juice, the cellulose cell walls of the fruit will be destroyed and dissolved so that it is more easily digested by the stomach and digestive tract. Fruit juice is one of the refreshing drinks for consumers. Quality fruit juice must be supported by choosing the right fruit.

Based on this background, a research was conducted on "The Effect of Addition of Manalagi (Malus sylvestris) Apple Juice to the Sensory Quality of Chewy Candy". The use of manalagi apples can be an alternative for the taste of chewy candy, to improve the sensory quality of chewy candy and be accepted by the general public.

\section{RESEARCH METHODS}

The research design used in this study was to make chewy candy with the addition of manalagi apple cider with different percentages, namely $20 \%, 40 \%$, and $60 \%$. The data obtained from the organoleptic assessment of chewy candy with the addition of manalagi apple juice will be analyzed using the Kruskal-Wallis test, if there is an effect, it will be continued with the Tuckey's test. The analysis test was carried out at the $95 \%$ confidence level $(\alpha=0.05)$.

\section{Organoleptic Test}

\section{RESULTS AND DISCUSSION}

In this study, the assessment of chewy candy with the addition of manalagi apple juice which includes: color, sweetness, taste of manalagi apple, aroma of manalagi apple, and texture. Sample code 054 for chewy candy with the addition of $20 \%$ manalagi apple cider (A), 019 chewy candy with the addition of 40\% manalagi apple cider (B), 198 chewy candy with the addition of $60 \%$ manalagi apple cider (C).

Table 1. Aspects of Color Assessment 
Farihah Bilqis Safira, Mariani, Mutiara Dahlia

\begin{tabular}{|c|c|c|c|c|c|c|c|}
\hline \multirow{3}{*}{$\begin{array}{l}\text { Assessment } \\
\text { Aspect }\end{array}$} & \multirow{3}{*}{ Score } & \multicolumn{6}{|c|}{ Manalagi Apple Cider Percentage Score (\%) } \\
\hline & & \multicolumn{2}{|c|}{$20 \%$} & \multicolumn{2}{|c|}{$40 \%$} & \multicolumn{2}{|c|}{$60 \%$} \\
\hline & & $\mathrm{n}$ & $\%$ & $\mathrm{n}$ & $\%$ & $\mathrm{n}$ & $\%$ \\
\hline $\begin{array}{l}\text { Yellowish } \\
\text { Green }\end{array}$ & 2 & 7 & 45 & - & - & 8 & 55 \\
\hline Dark Green & 3 & - & - & - & - & 2 & 15 \\
\hline $\begin{array}{l}\text { Slightly } \\
\text { Dark Green }\end{array}$ & 5 & 1 & 10 & 6 & 25 & 1 & 5 \\
\hline $\begin{array}{l}\text { Light } \\
\text { Green }\end{array}$ & 4 & 7 & 45 & 9 & 75 & 1 & 5 \\
\hline $\begin{array}{l}\text { Brownish } \\
\text { Green }\end{array}$ & 1 & - & - & - & - & 3 & 20 \\
\hline Total & & 15 & 100 & 15 & 100 & 15 & 100 \\
\hline Mean & & 3,1 & & 4,4 & & 2,2 & \\
\hline
\end{tabular}

Note: $\mathrm{n}=$ number of panelists; $\%=$ number of panelists in percent

For the results of the organoleptic test assessment with the addition of $20 \%$ manalagi apple cider, the highest value was 3.1 . For $40 \%$, manalagi apple cider has the highest score of 4.4. For $60 \%$ manalagi apple cider has the highest value of 2.2. Based on the descriptive results of the organoleptic test, the assessment of the moderately trained panelists on the chewy candy color of manalagi apple cider showed that the overall average score was 4.4 where the value was in the light green color category.

Analysis of the data used to test the hypothesis is the Friedman test, because the data in this study are non-parametric data. Non-parametric data to test the initial hypothesis that several samples come from the same/identical population. After being calculated using the Friedman test, Xcount $=26.81$ was obtained. This value shows Xcount $>$ Xtable. So H0 is rejected and H1 is accepted, meaning that there is an effect of adding $20 \%, 40 \%$, and $60 \%$ apple juice to the sensory quality of chewy candy on the color aspect, so it needs to be continued with multiple comparisons (Tuckey Test).

Couple Double Comparison

$|\mathrm{A}-\mathrm{B}|=|3.1-4.4|=1.3>0.13=>$ Significantly Different

$|\mathrm{A}-\mathrm{C}|=|3.1-2.2|=0.9<0.13 \Rightarrow>$ Not Significantly Different

$|\mathrm{B}-\mathrm{C}|=|4.4-2.2|=2.2>0.13 \Rightarrow>$ Significantly Different

The assessment in the multiple comparison test above shows that the data group at the time of manufacture of $20 \%$ (A) and $40 \%$ (B) showed a significantly different color quality in chewy candy. At the time of manufacture $20 \%$ (A) with $60 \%$ (C) showed sensory quality that was not significantly different. Then when making $40 \%$ (B) with $60 \%$ (C) it showed a significantly different sensory quality. It can be concluded that the production time of $20 \%$ with a score of 3.1 is the product with the best sensory quality in the chewy candy color aspect because at the percentage of 20\% it has an average value.

Table 2. Aspects of Sweet Taste Assessment

\begin{tabular}{|c|c|c|c|c|c|c|c|}
\hline \multirow{3}{*}{$\begin{array}{l}\text { Assessment } \\
\text { Aspect }\end{array}$} & \multirow{3}{*}{ Score } & \multicolumn{6}{|c|}{ Manalagi Apple Cider Percentage Score (\%) } \\
\hline & & \multicolumn{2}{|c|}{$20 \%$} & \multicolumn{2}{|c|}{$40 \%$} & \multicolumn{2}{|c|}{$60 \%$} \\
\hline & & $\mathrm{N}$ & $\%$ & $\mathrm{n}$ & $\%$ & $\mathrm{n}$ & $\%$ \\
\hline Very Sweet & 4 & - & - & - & - & 6 & 50 \\
\hline Sweet & 5 & 8 & 70 & 14 & 95 & 4 & 15 \\
\hline $\begin{array}{l}\text { Slightly } \\
\text { Sweet }\end{array}$ & 3 & 6 & 25 & - & - & 5 & 35 \\
\hline Not Sweet & 2 & 1 & 5 & 1 & 5 & - & - \\
\hline $\begin{array}{ll}\text { Very } & \text { Not } \\
\text { Sweet } & \end{array}$ & 1 & - & - & - & - & - & - \\
\hline Jumla & $\mathrm{h}(\mathrm{n})$ & 15 & 100 & 15 & 100 & 15 & 100 \\
\hline
\end{tabular}


Eduvest - Journal of Universal Studies

Volume 1 Number 8, August 2021

Mean

4.0

4,8

3,9

Note: $\mathrm{n}=$ number of panelists; $\%=$ number of panelists in percent 
For the results of the organoleptic test assessment with the addition of $20 \%$ manalagi apple cider, the highest value was 4.0 . For $40 \%$ manalagi apple cider has the highest value of 4.8. For $60 \%$ manalagi apple cider has the highest value of 3.9. Based on the descriptive results of the organoleptic test, the assessment of moderately trained panelists on the sweet taste of manalagi apple cider chewy candy showed that the overall average score was 4.8 where the value was in the sweet taste category.

Analysis of the data used to test the hypothesis is the Friedman test, because the data in this study are non-parametric data. Non-parametric data to test the initial hypothesis that several samples come from the same/identical population. After being calculated using the Friedman test, Xcount $=24.92$. This value shows Xcount $>$ Xtable. So $\mathrm{H} 0$ is rejected and $\mathrm{H} 1$ is accepted, meaning that there is an effect of adding $20 \%, 40 \%$, and $60 \%$ apple juice to the sensory quality of chewy candy on the sweet taste aspect, so it needs to be continued with a double comparison (Tuckey Test).

Couple Double Comparison

$|\mathrm{A}-\mathrm{B}|=|4.0-4.8|=0.8<0.11 \Rightarrow$ Not Significantly Different

$|\mathrm{A}-\mathrm{C}|=|4.0-3.9|=0.1<0.11 \Rightarrow$ Not Significantly Different

$|\mathrm{B}-\mathrm{C}|=|4.8-3.9|=0.9<0.11 \Rightarrow>$ Not Significantly Different

The assessment in the multiple comparison test above shows that the data group at the time of manufacture of $20 \%$ (A) and $40 \%$ (B) showed the quality of sweetness in chewy candy which was not significantly different. At the time of manufacture $20 \%$ (A) with $60 \%(\mathrm{C})$ showed sensory quality that was not significantly different. Then when making $40 \%$ (B) with $60 \%$ (C) it showed sensory quality which was not significantly different. It can be concluded that the production time of $20 \%$ with a score of 4.0 is the product with the best sensory quality in terms of the sweet taste of chewy candy because at a percentage of $20 \%$ it has an average value.

Table 3. Aspects of the Manalagi Apple Taste Assessment

\begin{tabular}{|c|c|c|c|c|c|c|c|}
\hline \multirow{3}{*}{ Assessment Aspect } & \multirow{3}{*}{ Score } & \multicolumn{6}{|c|}{ Manalagi Apple Cider Percentage Score (\%) } \\
\hline & & \multicolumn{2}{|c|}{$20 \%$} & \multicolumn{2}{|c|}{$40 \%$} & \multicolumn{2}{|c|}{$60 \%$} \\
\hline & & $\mathrm{n}$ & $\%$ & $\mathrm{n}$ & $\%$ & $\mathrm{n}$ & $\%$ \\
\hline Very Tasted Manalagi & 4 & - & - & 3 & 15 & 2 & 10 \\
\hline Tasted Manalagi Apple & 5 & 8 & 75 & 8 & 65 & 5 & 30 \\
\hline $\begin{array}{l}\text { Somewhat Taste of } \\
\text { Manalagi Apple }\end{array}$ & 3 & 2 & 10 & 3 & 15 & 6 & 50 \\
\hline $\begin{array}{l}\text { No Taste of Manalagi } \\
\text { Apple }\end{array}$ & 2 & 3 & 15 & 1 & 5 & 1 & 5 \\
\hline $\begin{array}{l}\text { Very Not Taste Manalagi } \\
\text { Apple }\end{array}$ & 1 & - & - & & & & 5 \\
\hline Total (n) & & 15 & 100 & 15 & 100 & 15 & 100 \\
\hline Mean & & 4,0 & & & & & 3,6 \\
\hline
\end{tabular}

Note: $\mathrm{n}=$ number of panelists; $\%=$ number of panelists in percent

For the results of the organoleptic test assessment with the addition of $20 \%$ manalagi apple cider, the highest value was 4.0 . For $40 \%$ manalagi apple cider has the highest value of 4.2. For $60 \%$ manalagi apple cider has the highest value of 3.6. Based on the descriptive results of the organoleptic test, the assessment of the moderately trained panelists on the taste of manalagi chewy candy apple juice showed that the overall average value was 4.2 where the value was in the manalagi apple flavored category.

Analysis of the data used to test the hypothesis is the Friedman test, because the data in this study are non-parametric data. Non-parametric data to test the initial hypothesis that several samples come from the same/identical population. After being 
calculated using Friedman's test, Xcount $=23.90$. This value shows Xcount $>$ Xtable. Then $\mathrm{H} 0$ is rejected and $\mathrm{H} 1$ is accepted, meaning that there is an effect of adding $20 \%$, $40 \%$, and $60 \%$ manalagi apple juice on the sensory quality of chewy candy on the manalagi apple flavor aspect, so it needs to be continued with a double comparison (Tuckey test).

Couple Double Comparison

$|\mathrm{A}-\mathrm{B}|=|4.0-4.2|=0.2<0.18 \Rightarrow>$ Not Significantly Different

$|\mathrm{A}-\mathrm{C}|=|4.0-3.6|=0.4<0.18=>$ Not Significantly Different

$|\mathrm{B}-\mathrm{C}|=|4.2-3.6|=0.6<0.18=>$ Not Significantly Different

The assessment in the multiple comparison test above shows that the data group at the time of manufacture of $20 \%$ (A) and $40 \%$ (B) shows the quality of the taste of apples, which in chewy candy is not significantly different. At the time of manufacture $20 \%$ (A) with $60 \%$ (C) showed sensory quality that was not significantly different. Then when making $40 \%$ (B) with $60 \%$ (C) it showed sensory quality which was not significantly different. It can be concluded that the production time of $20 \%$ with a score of 4.0 is the product with the best sensory quality in the aspect of apple flavor, which is chewy candy because at the percentage of $20 \%$ it has an average value.

Table 4. Aspects of Assessment of Manalagi Apple Aroma.

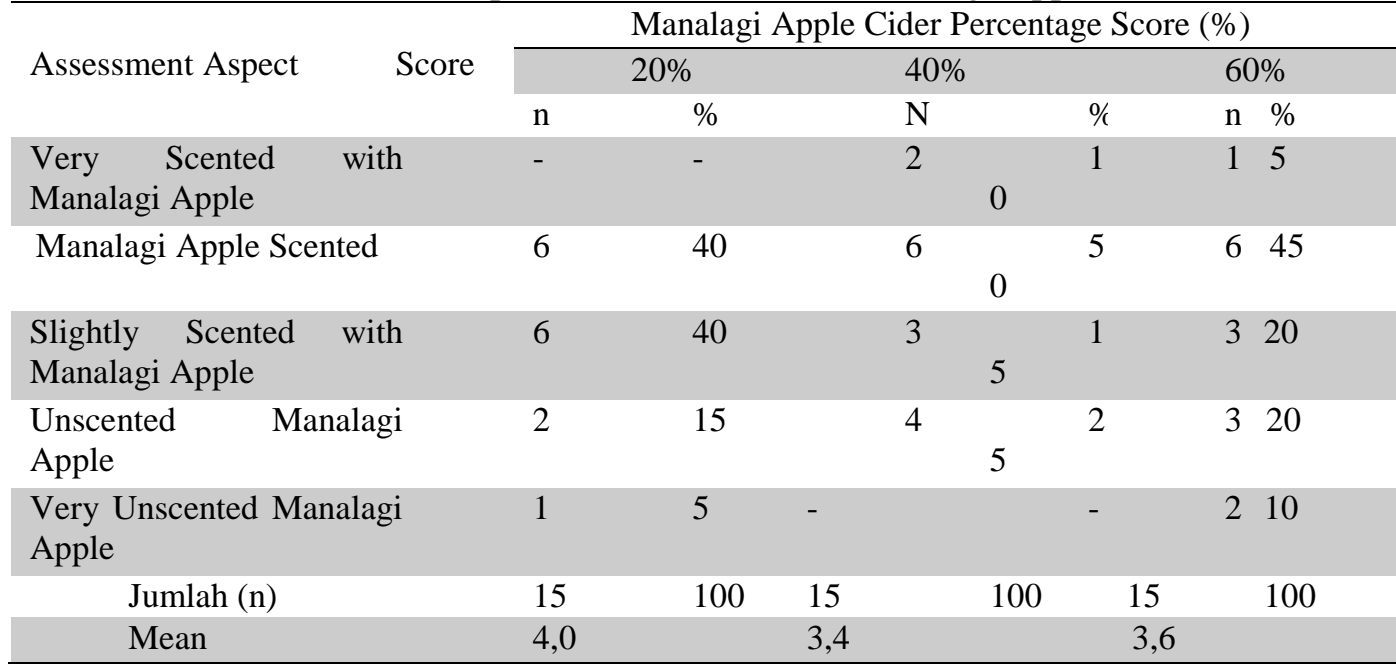

Note: $\mathrm{n}=$ number of panelists; $\%=$ number of panelists in percent

For the results of the organoleptic test assessment with the addition of $20 \%$ manalagi apple cider, the highest value was 4.0 . For $40 \%$ manalagi apple cider has the highest value of 3.4. For $60 \%$ manalagi apple cider has the highest value of 3.6. Based on the descriptive results of the organoleptic test, the assessment of the moderately trained panelists on the taste of manalagi chewy candy apple juice showed that the overall average value was 4.0 where the value was close to the manalagi apple flavored category.

Analysis of the data used to test the hypothesis is the Friedman test, because the data in this study are non-parametric data. Non-parametric data to test the initial hypothesis that several samples come from the same/identical population. After being calculated using the Friedman test, Xcount $=23.74$. This value shows Xcount $>$ Xtable. So $\mathrm{H} 0$ is rejected and $\mathrm{H} 1$ is accepted, meaning that there is an effect of adding $20 \%, 40 \%$, and $60 \%$ manalagi apple juice on the sensory quality of chewy candy on the aroma aspect of manalagi apples, so it needs to be continued with multiple comparisons (Tuckey Test).

Couple Double Comparison

$|A-B|=|4.0-3.4|=0.6<0.27 \Rightarrow>$ Not Significantly Different 
$|A-C|=|4.0-3.6|=0.4<0.27 \Rightarrow>$ Not Significantly Different

$|\mathrm{B}-\mathrm{C}|=|3.4-3.6|=0.2<0.27=>$ Not Significantly Different

The assessment in the multiple comparison test above shows that the data group at the time of manufacture of $20 \%$ (A) and $40 \%$ (B) shows the quality of the apple aroma, which is not significantly different from chewy candy. At the time of manufacture $20 \%$ (A) with $60 \%$ (C) showed sensory quality that was not significantly different. Then when making $40 \%$ (B) with $60 \%$ (C) it showed sensory quality which was not significantly different. It can be concluded that the production time of $40 \%$ with a score of 3.4 is the product with the best sensory quality in the aspect of apple aroma, manalagi chewy candy, because $40 \%$ has an average value.

Table 5. Aspects of Texture Assessment

\begin{tabular}{|c|c|c|c|c|c|c|c|c|c|c|}
\hline \multirow{3}{*}{ Assessment Aspect } & \multirow{3}{*}{ Score } & \multicolumn{9}{|c|}{ Manalagi Apple Cider Percentage Score (\%) } \\
\hline & & \multicolumn{3}{|c|}{$20 \%$} & \multicolumn{2}{|c|}{$40 \%$} & \multicolumn{3}{|c|}{$60 \%$} & \\
\hline & & & $\mathrm{n}$ & & $\mathrm{n}$ & $\%$ & & $\mathrm{n}$ & $\%$ & \\
\hline Very supple & 5 & 3 & 15 & 4 & & 20 & & 7 & 60 & \\
\hline Supple & 4 & 6 & 45 & & 8 & 65 & & 5 & 25 & \\
\hline Agak Kenyal & 3 & 4 & 30 & & 3 & 15 & & 3 & 15 & \\
\hline Not Supple & 2 & 1 & 5 & & - & & - & - & & - \\
\hline Very Not Supple & 1 & 1 & 5 & & - & & - & - & & - \\
\hline Jumlah (n) & & 15 & 100 & 15 & & 100 & & 15 & 100 & \\
\hline Mean & & 3,6 & & & $4, \mathrm{C}$ & & & & & \\
\hline
\end{tabular}

Note: $\mathrm{n}=$ number of panelists; $\%=$ number of panelists in percent

For the results of the organoleptic test assessment with the addition of $20 \%$ manalagi apple cider, the highest value was 3.6. For $40 \%$ manalagi apple cider has the highest value of 4.0. For $60 \%$ manalagi apple cider has the highest value of 4.2. Based on the descriptive results of the organoleptic test, the assessment of the moderately trained panelists on the chewy candy texture of manalagi apple cider showed that the overall average value was 4.0 where the value was close to the chewy category.

Analysis of the data used to test the hypothesis is the Friedman test, because the data in this study are non-parametric data. Non-parametric data to test the initial hypothesis that several samples come from the same/identical population. After being calculated using Friedman's test, Xcount $=19.40$. This value shows Xcount $>$ Xtable. So $\mathrm{H} 0$ is rejected and $\mathrm{H} 1$ is accepted, meaning that there is an effect of adding $20 \%, 40 \%$, and $60 \%$ apple juice to the sensory quality of chewy candy in the texture aspect, so it needs to be continued with multiple comparisons (Tuckey Test).

Couple Double Comparison

$|\mathrm{A}-\mathrm{B}|=|3.6-4.0|=0.4<0.11=>$ Not Significantly Different

$|\mathrm{A}-\mathrm{C}|=|3.6-4.2|=0.6<0.11 \Rightarrow>$ Not Significantly Different

$|\mathrm{B}-\mathrm{C}|=|4.0-4.2|=0.2<0.11 \Rightarrow$ Not Significantly Different

The assessment in the multiple comparison test above shows that the $20 \%$ (A) and $40 \%$ (B) data group showed that the chewy candy apple texture quality was not significantly different. At the time of manufacture $20 \%$ (A) with $60 \%$ (C) showed sensory quality that was not significantly different. Then when making $40 \%$ (B) with $60 \%$ (C) it showed sensory quality which was not significantly different. It can be concluded that the $40 \%$ manufacturing time with a score of 4.0 is the product with the best sensory quality in the chewy candy apple texture aspect because at $40 \%$ it has the highest value.

\section{CONCLUSION}


The final conclusion shows that the best product chosen is the chewy candy apple manalagi with a percentage of $40 \%$, this is based on the Tuckey's test showing different results, namely: in the sweet taste aspect, the manalagi apple taste aspect, the manalagi apple aroma aspect, and the texture aspect has 3 results. which was not significantly different, while in the color aspect there were 2 results, namely: 1 which was not significantly different and 2 significantly different, this result was chosen because of the good quality, which has a light green color, sweet taste, manalagi apple taste, and a chewy texture.

\section{REFERENCES}

Adnandiyanta, Rengga, \& Hermawan, Adira. (2016). Pengambilan Pektin Dari Limbah Industri Rumahan Sari Buah (Variabel Berat Bahan Dan Konsentrasi Pelarut). Jurnal Inovasi Proses, 1(1), 28-34.

Azizah, Muthia Nur. (2019). Pengaruh Perbandingan Sari Talas (Colocasia Esculenta) Dengan Sari Black Mulberry (Morus Nigra. L) Dan Konsentrasi Cmc Terhadap Karakteristik Minuman Sari "Lasberry. Fakultas Teknik Unpas.

Hamidah, Siti. (2015). Sayuran dan Buah serta Manfaatnya bagi Kesehatan. Artikel Ilmiah. Fakultas Teknik Universitas Negeri Yogyakarta.

Kurniati, Eka, Silvia, Evanila, \& Efendi, Zulman. (2016). Analisis kepuasan konsumen terhadap kue baytat Bengkulu. Jurnal Teknologi Dan Industri Pertanian Indonesia, $8(2), 67-75$.

Leksono, Amien S. (2010). Keanekaragaman hayati. Universitas Brawijaya Press.

Muhlisin, Ahmad, Karindah, Sri, \& Rahardjo, Bambang Tri. (2015). Populasi Kutu Sisik Diaspidiotus Perniciosus Comstock (Hemiptera: Diaspididae) Dan Parasitoidnya Pada Pertanaman Apel (Malus Sylvestris L)(Studi Kasus Di Kecamatan Pujon Dan Bumiaji Kota Batu). Jurnal Hama Dan Penyakit Tumbuhan, 3(1), pp-109.

Mustollah, Hafit. (2016). Analisa Profil Protein Gelatin Sapi dan Gelatin Babi Gummy Vitamin C Menggunakan Metode SDSPAGE (Sodium Dodecyl Sulphate Poly Acrylamide Gel Electrophoresis).

Nisrina, Hajar Hanif. (2018). Karakteristik Fisik, Kimia dan Sensoris Cookies Beras Hitam (Oryza Sativa L.). Universitas Muhammadiyah Semarang.

Nurdjannah, Nanan. (2007). Teknologi pengolahan pala. Badan Penelitian Dan Pengembangan Pertanian, Balai Besar Penelitian Dan Pengembangan Pasca Panen Pertanian.

Sa'adah, Lailufary Ichda Noor, \& Estiasih, Teti. (2014). Karakterisasi Minuman Sari Apel Produksi Skala Mikro Dan Kecil Di Kota Batu: Kajian Pustaka [In Press April 2015]. Jurnal Pangan Dan Agroindustri, 3(2), 374-380.

Sari, Devi Ardiana. (2016). Rekayasa Atmosfer Terhadap Konsentrasi Gas Co2 Dan O2 Guna Meningkatkan Usia Simpan Buah Dalam Kotak Berpendingin Es Kering. Institut Teknologi Sepuluh Nopember Surabaya.

Sihombing, Dewi Elfrida. (2013). Karakteristik kimia dan mikrobiologi yoghurt probiotik susu kambing dengan penambahan ekstrak bunga rosella (Hibiscus sabdariffa L).

Sipahelut, Sophia G., Rejeki, Sri, \& Patty, John Alfred. (n.d.). Kandungan Vitamin C Dan Preferensi Konsumen Terhadap Selai Lembaran Pala Dengan Penambahan Sari Buah Naga. Jurnal Sains Dan Teknologi Pangan, 5(3).

Sutanto, Agus, \& Ambarsari, Indrie. (2016). Aneka Produk Olahan Berbasis Sumber Daya Lokal. BPTP Jateng.

Widiati, Nenik. (2019). Pembuatan permen jelly dari bahan dasar bayam. UNS (Sebelas Maret University). 